\title{
Improvement of efficiency on Tanjung Marolan farmers process with thresher technology
}

\author{
Agus Salim Harahap ${ }^{1 *}$, Esther Sorta Nababan ${ }^{1}$, Nelson M.Siahaan ${ }^{2}$, Meyman Sokhi Ziliwu ${ }^{3}$ \\ ${ }^{1}$ Faculty of Mathematics and Natural Sciences, Universitas Sumatera Utara \\ ${ }^{2}$ Faculty of Engineering, Universitas Sumatera Utara \\ ${ }^{3}$ Faculty of Computer Science and Information Technology, Universitas Sumatera Utara \\ *Email: agus6@usu.ac.id
}

\begin{abstract}
Human labor that is always relied upon every time entering the harvest season is one condition that must be considered by every farmer, especially in the rice harvest process. Farmers in Ajibaho village especially in Dusun VII Tanjung Marolan still carry out the stages of harvesting rice with simple equipment using human labor. Some stages of the harvest process require a relatively long time. Starting from cutting rice stalks, collecting rice stalks, threshing rice by hitting rice on a drum so that the rice will fall from rice stems. Then the rice is collected and then put into a sack and then transported to the house. This condition also depends on the weather at the time of harvest. Rainy or dry weather sometimes makes the harvest stages take longer than expected. Simple technology using a rice thresher machine (thresher) can be a solution to achieve efficiency at the stage of the harvest process, especially in the process of threshing rice from the stem which has so far been carried out simply using human labor. After the application of this simple technology has an impact with increased yields, reduced spending on people working daily, time spent more efficiently.
\end{abstract}

Keyword: Rice thresher (thresher), simple equipment, efficiency

\begin{abstract}
Abstrak
Tenaga manusia yang selalu diandalkan setiap memasuki musim panen merupakan salah satu kondisi yang mesti diperhatikan oleh setiap petani khususnya pada proses panen padi. Petani di Desa Ajibaho khusunya di Dusun VII Tanjung Marolan masih melaksanakan tahapan panen padi dengan peralatan sederhana menggunakan tenaga manusia. Beberapa tahapan proses panen memerlukan waktu yang relative lama. Dimulai dari pemotongan batang padi, pengumpulan batang padi, perontokkan padi dengan memukulkan padi pada sebuah drum sehinggga padi akan rontok dari batang padi. Kemudian padi dikumpulkan lalu dimasukkan kedalam karung kemudian diangkut kerumah. Kondisi ini juga bergantung pada cuaca pada saat panen. Cuaca hujan atau kemarau terkadang membuat tahapan panen menjadi lebih lama pelaksanaan dari yang diperkirakan. Teknologi sederhana menggunakan mesin perontok padi (thresher) dapat menjadi solusi tercapainya efisiensi pada tahapan proses panen khususnya pada proses perontokkan padi dari batangnya yang selama ini masih dilakukan secara sederhana menggunakan tenaga manusia. Setelah penerapan teknologi sederhana ini memberikan dampak dengan hasil panen meningkat, berkurangnya pengeluaran orang harian kerja, waktu yang digunakan lebih efisien.
\end{abstract}

\section{Kata Kunci : Perontok padi (thresher), peralatan sederhana, efisiensi}

\section{PENDAHULUAN}

\subsection{Analisis Situasi}

Pertanian merupakan salah satu industri terbesar di dunia. United Nations Food and Agricultural Organitation (UNFAO) memaparkan dalam sektor ini mempekerjakan kurang lebih 1.3 milyar manusia secara langsung dilahan pertanian di seluruh dunia. Indonesia merupakan salah satu negara di dunia dengan lahan pertanian yang sangat luas. Penduduk masih menjadikan beras bahan makanan pokok untuk kehidupan sehari-hari. Warga Desa Ajibaho Kecamatan Birubiru umumnya merupakan petani sawah yang menanam padi. Namun seiring waktu berjalan warga masyarakat sudah banyak yang tidak lagi menjadi petani oleh karena pekerjaan petani sawah 
dengan menanam padi membutuhkan proses lama sehingga untuk mendapatkan untung dan upah hanya pada saat proses panen. Peralatan sederhana yang digunakan untuk melaksanakan tahapan proses merontokkan padi dengan menggunakan drum yang sudah tidak digunakan lagi tampak pada Gambar 1.1 dibawah ini.

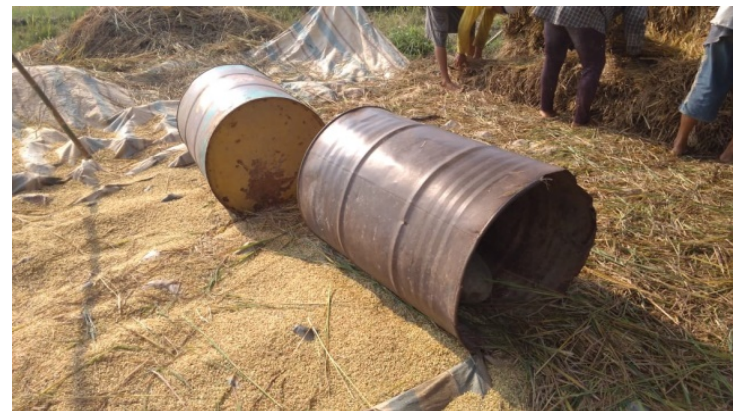

Gambar 1.1. Peralatan Sederhana yang Digunakan pada Saat Perontokkan Padi

Untuk melaksanakan perontokkan padi menggunakan drum yang sudah tidak dipakai lagi dengan memukulkan batang dan dan daun padi sekaligus padi ke drum tersebut. Oleh karena itu, padi jatuh dan terpisah dari batang padi tersebut, tampak seperti pada Gambar 1.2. dibawah ini.

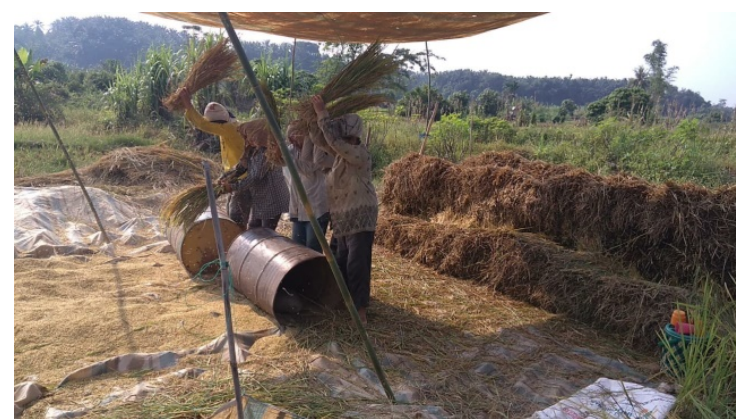

Gambar 1.2. Proses Perontokkan Padi Menggunakan Drum Bekas.

Keseluruhan tahapan proses panen padi khususnya untuk perontokkan padi ternyata tidak efisiensi oleh karena waktu yang lama dan tenaga manusia yang terbatas.

Tingginya kehilangan hasil karena terbuang bersama sampah seperti batang dan daun padi merupakan salah satu faktor yang menyebabkan tidak maksimal hasil panen. Tingkat kehilangan hasil padi selama penanganan pascapanen mencapai 20-21\%, yang terbesar terjadi pada pemanenan, yaitu sektar 9\% dan pada perontokan sekitar 5\% (E E et al.).

Proses panen padi yang telah dilakukan pada sebuah lahan dengan luas 5500 M2, mulai dari memotong padi yang dilakukan oleh 8 orang selama 1 hari, menumpukkan padi oleh 4 orang selama 2 hari, proses perontokkan padi dengan memakai alat sederhana (Gambar 1.2) oleh 8 orang selama 2 hari dan setelah siap dimuat dalam goni/karung lalu diangkut oleh 2 orang, sehingga diperlukan waktu 6 hari mulai dari potong padi hingga siap angkut. Upah hari orang kerja (HOK) Rp. 70.000. Situasi ini masih normal karena cuaca yang mendukung namun bila cuaca kurang mendukung waktu yang dibutuhkan semakin lama. Dana yang dibutuhkan pada proses panen juga sangat besar.

\subsection{Permasalahan Mitra}

a. Melaksanakan panen padi masih menggunakan peralatan sederhana dengan tenaga manusia.

b. Masih terdapat banyak sampah batang padi dan daunnya pada saat proses pengeringan padi. 
c. Pekerja upahan yang sudah semakin sedikit mengakibatkan proses panen padi kurang maksimal.

d. Waktu yang diperlukan makin lama bila cuaca yang kurang mendukung pada saat proses panen padi

\section{METODE PELAKSANAAN}

\subsection{Pembuatan Perontok Padi (Thresher)}

Ada 3 hal penting dalam pembuatan mesin perontok padi yaitu tempat pemasukan padi, proses perontokkan dan unit kipas (Olugboji OA). Untuk mendapatkan hasil yang maksimal perlu diperhatikan pengaruh putar silinder dari mesin padi terhadap mutu padi(I W et al.). Desain yang digunakan untuk menyelesaikan permasalahan yang dihadapi mitra, telah dirancang sebagaimana ditunjukkan pada lampiran 2. Material yang dibutuhkan tersedia dipasar lokal dan mudah untuk mendapatkannya, dan dikerjakan oleh tukang sesuai dengan rancangan yang diinginkan.

\subsection{Metode Pelaksanaan yang Ditawarkan dan Disepakati Bersama Mitra}

Berdasarkan permasalahan yang telah diidentifikasi pada kedua mitra, metode pendekatan yang digunakan adalah sosialisasi, pelatihan penggunaan dan pemeliharaan dan pendampingan. Secara rinci, langkah-langkah yang akan dilakukan oleh perguruan tinggi pembina bersama mitra sebagai berikut:

1. Memberi penjelasan dan penyuluhan tentang pentingnya penerapan teknologi sederhana pada proses panen padi khususnya pada tahapan perontokkan padi sehingga efisiensi waktu lebih maksimal.

2. Memberi penjelasan fungsi perontok padi (Thresher).

3. Menyiapkan SOP tentang pentingnya teknologi sederhana.

4. Memberikan penyuluhan tentang pentingnya kerjasama kelompok tani pada proses panen padi.

\subsection{Rencana Prosedur Kegiatan dan Partisipasi Mitra Dalam Pelaksanaan Program}

Tabel. 2.1. Rencana Kegiatan dan Partisipasi Mitra

\begin{tabular}{|c|c|c|c|c|}
\hline No & Aplikasi Kegiatan & $\begin{array}{c}\text { Metode } \\
\text { Pendekatan }\end{array}$ & Target & Partisipasi Mitra \\
\hline 1. & $\begin{array}{l}\text { Penyebaran informasi } \\
\text { tentang pentingnya } \\
\text { efisiensi pada proses } \\
\text { panen padi. }\end{array}$ & Sosialisasi & $\begin{array}{l}\text { Mitra } \\
\text { (Kelompok } \\
\text { tani) }\end{array}$ & $\begin{array}{l}\text { Membuat komitmen kerjasama dan } \\
\text { menyediakan tempat pada proses } \\
\text { panen padi }\end{array}$ \\
\hline 2. & $\begin{array}{l}\text { Persiapan pembuatan } \\
\text { perontok padi (Thresher) }\end{array}$ & $\begin{array}{l}\text { Pembelian } \\
\text { bahan dan } \\
\text { alat }\end{array}$ & $\begin{array}{l}\text { Mitra } \\
\text { (Kelompok } \\
\text { tani) }\end{array}$ & $\begin{array}{l}\text { Memberikan informasi pendukung } \\
\text { mengenai perontok padi (Thresher), } \\
\text { ukuran, berat dan volume yang } \\
\text { diharapkan kelompok tani. }\end{array}$ \\
\hline 3. & $\begin{array}{l}\text { Standard Operating } \\
\text { System (SOP) }\end{array}$ & $\begin{array}{l}\text { Sosialisasi } \\
\text { dan } \\
\text { Aplikasi }\end{array}$ & $\begin{array}{l}\text { Mitra } \\
\text { (Kelompok } \\
\text { tani) }\end{array}$ & $\begin{array}{l}\text { Mempelajari SOP yang telah dibuat } \\
\text { dan mematuhinya }\end{array}$ \\
\hline 4. & $\begin{array}{l}\text { Penggunaan perontok } \\
\text { padi (Thresher) }\end{array}$ & $\begin{array}{l}\text { Sosialisasi } \\
\text { dan } \\
\text { Aplikasi }\end{array}$ & $\begin{array}{l}\text { Mitra } \\
\text { (Kelompok } \\
\text { tani) }\end{array}$ & $\begin{array}{l}\text { Mengikuti bagaimana } \\
\text { menggunakan perontok padi } \\
\text { (Thresher). }\end{array}$ \\
\hline 5. & Pemeliharaan perontok & Sosialisasi & Mitra & Mengikuti SOP yang telah dibuat. \\
\hline
\end{tabular}


Agus Salim Harahap et.al. Improvement of Efficiency

$\begin{array}{lll}\text { padi (Thresher) } & \text { dan } & \text { (Kelompok } \\ & \text { Aplikasi } & \text { tani) }\end{array}$

\section{HASIL DAN PEMBAHASAN}

Pada tahapan hasil dan luaran yang dicapai pada 100\% pelaksanaan Pengabdian kepada Masyarakat dimulai dari tahapan perancangana alat yang disesuaikan dengan usulan yang disampaikan. Berikut desain alat sesuai dengan Gambar 3.1 dibawah ini.

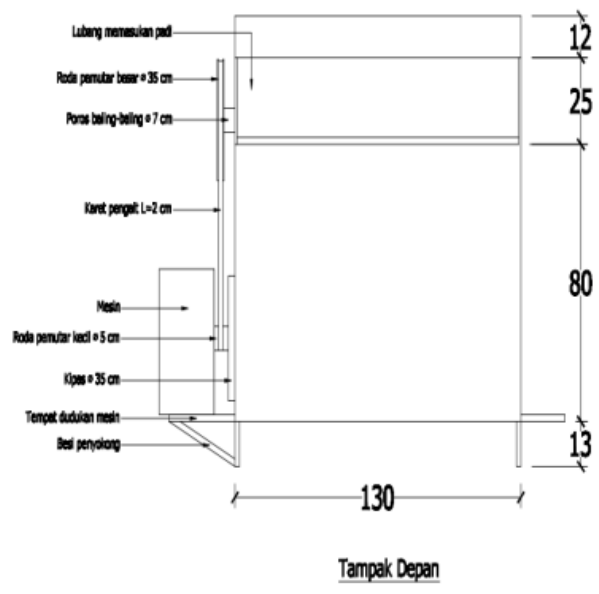

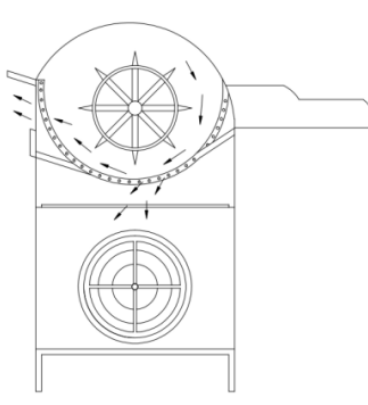

Tampak Potongan Samping

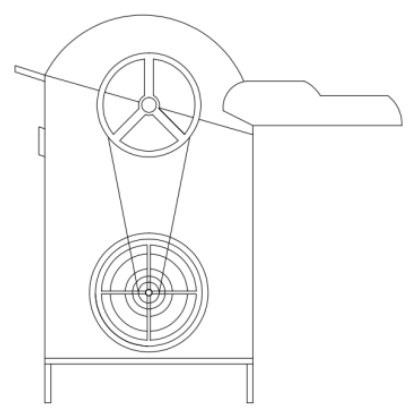

Tampak Samping Kiri

Gambar 3.1. Desain Teknologi Thresher

Pembuatan dan perakitan thresher telah dilaksanakan sesuai dengan desain yang disampaikan pada usulan sebelumnya. Mesin thresher ini diharapkan dapat menjadi solusi untuk memecahkan masalah yang dialami oleh kelompok tani tanjung marolan pada saat melaksanakan proses panen padi. Pada Gambar 3.2 menunjukkan thresher secara keseluruhan.

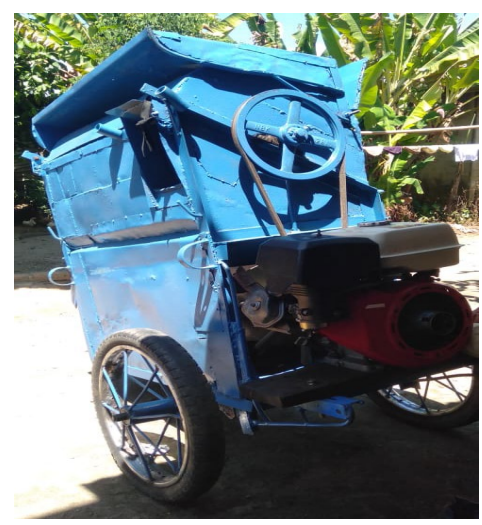

Gambar 3.2. Thresher

Pada Gambar 3.3 Menunjukkan mesin thresher yang telah siap digunakan untuk melaksanakan proses panen padi. Bagian penting mesin thresher yaitu (1) tempat memasukkan batang padi, (2) motor penggerak, (3) rotor pemutar untuk merontokkan padi, (4). Perangkat kipas, (5) Lubang keluaran sampah. Fungsi dan kegunaan masing-masing bagian yang ada pada mesin thresher dapat dilihat pada Gambar 3.3 dibawah ini. 


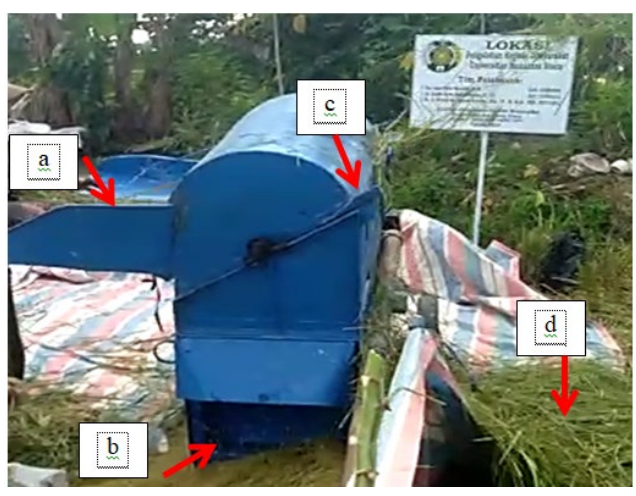

Gambar 3.3. Proses Implementasi Thresher

Mesin thresher digunakan untuk merontokkan padi. Batang padi dimasukkan ke mesin thresher, kemudian mesin thresher akan memproses dibantu oleh mesin motor, putaran didalam thresher akan merontokkan padi sehingga padi akan jatuh kemudian diproses untuk memisahkan padi yang berisi dan yang masih kosong. Padi yang kosong akan terbang karena didalam mesin thresher karena kipas thresher akan sehingga yang jatuh dibawah

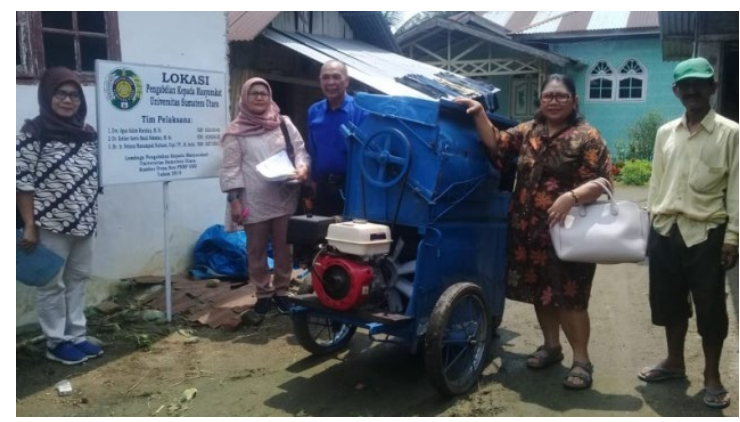

Gambar 3.4. Monitoring Lembaga Pengabdian USU

Dengan adanya teknologi thresher masyarakat tanjung marolan desa Ajibaho Kabupaten Deli Sedang merasa sangat senang. Masyarakat merasakan manfaat teknologi thresher karena terjadinya efisiensi setiap proses panen yang dilakukan. Peningkatan hasil panen karena proses perontokkan padi lebih maksimal sehingga padi sangat meminimalkan jumlah padi yang terbuang ke sampah batang padi. Selain hasil panen yang meningkat, waktu yang dibutuhkan juga singkat karena teknologi thresher dengan menggunakan motor mesin mampu merontokkan padi dalam jumlah maksimal, sehingga sangat berpengaruh pada tenaga kerja yang berkurang jumlahnya, dapat dilihat pada Grafik dibawah ini.

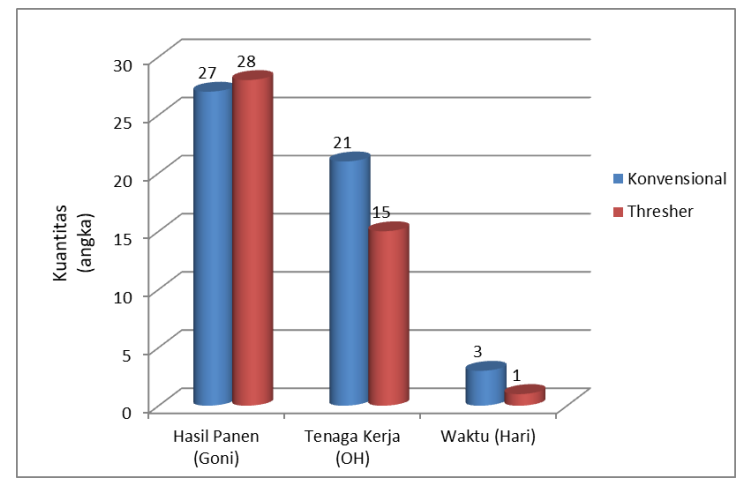

Gambar 3.5. Grafik Kuantitas Efisiensi Secara Konvensional dan Thresher 
Sesuai dengan Gambar 3.5 Grafik Kuantitas Efisiensi Secara Konvensional dan Thresher Diatas menunjukkan bahwa proses panen yang dilaksanakan sesuai dengan sampel dengan luas 7 rantai atau $(2800 \mathrm{~m} 2)$ meminimalisir pengeluaran dan meningkatkan pendapatan.

\section{KESIMPULAN DAN SARAN}

\subsection{Kesimpulan}

1. Teknologi sederhana thresher membuat padi tidak terbuang sehingga hasil panen lebih maksimal dan meningkat.

2. Dengan adanya teknologi thresher, Tenaga kerja manusia yang selama ini lebih minimal.

3. Proses panen padi lebih cepat dari waktu yang dikerjakan oleh tenaga kerja harian.

\subsection{Saran}

Pelaksanaan pengabdian masyarakat menjadi salah satu cara mendekatkan efisiensi pada masyarakat yang masih menggunakan alat sederhana untuk itu pengabdian masyarakat ini dapat dilanjutkan dengan berbagai teknologi lainnya.

\section{UCAPAN TERIMAKASIH}

Tim Pengabdi mengucapkan terima kasih kepada Lembaga Pengabdian Pada Masyarakat (LPPM) Universitas Sumatera Utara yang telah Memberikan dana dengan skema mono tahun 2019, Nomor : 327/UN5.2.3.2.1/PPM/2019, Tanggal 20 Mei 2019. Ucapan terima kasih juga disampaikan kepada mitra pengabdi, kelompok tani tanjung marolan yang membantu terlaksananya kegiatan Pengabdian Pada Masyarakat.

\section{DAFTAR PUSTAKA}

E E, Ananto, et al. 2003. Panduan Teknis Penangnan Panen Dan Pascapanen Padi Dalam System Usahatani Tanaman-Ternak. Puslibangtan: Puslitbangtan.

I W, Mulsanti, et al. 2007. Pengaruh Kecepatan Putar Silinder Mesin Perontok Terhadap Mutu Benih Padi. Balai Besar Penelitian Tanaman Padi: Balai Besar Penelitian Tanaman Padi

Olugboji OA. (2004). Development of a Rice Threshing Machine. AU J.T, vol. 8, no. 2, http://www.journal.au.edu/au_techno/2004/oct04/vol8num2_art04.pdf. 